\title{
Alkaloids and flavonoids from the air dried aerial parts of Citrullus colocynthis
}

\author{
Hediat M. H. Salama \\ Botany and Microbiology Department, Faculty of Science, King Saud University, Riyadh, Kingdom of Saudi Arabia. \\ E-mail: hoda.salama@hotmail.com.
}

Accepted 5 April, 2012

\begin{abstract}
From the air dried aerial parts of Citrullus colocynthis, two new alkaloids namely, 2-(nonan-8-one)-(1H)4-quinolone and 2-(Nonan-8-one) 4-methoxy-quinoline were isolated. Two flavonoids, (2S)-3, 4 methylenedioxy -5 , 7-dimethoxy flavan and hispidulin 7- (6-E - $\beta$ coumaroyl $-\beta-D$ glucopyranoside) were also extracted and identified. The structures were established by conventional methods of analysis and confirmed by UV, IR, ${ }^{1} \mathrm{H}$ and ${ }^{13} \mathrm{CNMR}$, and mass spectra.
\end{abstract}

Key words: Citrullus colocynthis, cucurbitaceae, new quinoline, quinolone alkaloids, flavonoids.

\section{INTRODUCTION}

Citrullus colocynthis (L.) is an important medicinal plant belonging to the family cucurbitaceae. It is an annual herb widely distributed in Mediterranean strip (Tackholm, 1974). The plant is prostrate, herbaceous characterized by 5 -angled stems and coiled tendrils, leaves alternate, palmately 5-lobed or divided, exstipulate and flowers are unisexual and solitary (Täckholm, 1974; Chaudhary and Al-jowaid, 1999). Nowadays, medicinal plants receive attention to research centers because of their special importance in safety of communities. The curative properties of medicinal plants are mainly due to the presence of various complex chemical substances of different composition which occur as secondary metabolites (Karthikeyan et al., 2009). Several active chemical constituents of $C$. colocynthis plant were recorded. They are grouped as alkaloids, flavonoids, saponins, tannins, carbohydrates, glycosides and essential oils. Plant based natural constituents can be derived from any part of the plant like stems, leaves, flowers, roots, fruits and seeds (Gordon and David, 2001). A number of plant secondary metabolites including flavonoids and curcubitacins have previously been reported from C. colocynthis (Maatooq et al., 1997; Seger et al., 2005). Adam et al. (2001) reported the bitter substances (colocynthin and colocythetin) and cucurbitacins A, B, C, D and E ( $\alpha$ - elatrin); cucurbitacines E, I, J, K and L (Sturm et al., 2009), cucurbitacin glycosides (Hatam et al., 1989; Abbas et al., 2006). The cucurbitacins are of great interest because of the wide range of biological activities exhibited in plants and animals. They are predominantly found in the Cucurbitaceae family. A number of chemical constituents have been investigated for their cytotoxic, heptoprotective, cardiovascular and antidiabetic effects and antioxidant activity of cucurbitacins B and I (Jayaprakasam et al., 2003) and the glucosides of cucurbitacin I and L (Abbas et al., 2006).

Sunil et al. (2008) studied antioxidant and free radical scavenging potential of $C$. colocynthis methanolic fruit extract. C. colocynthis is also one of the plants belonging to family cucurbitaceae. It is a fruit commonly known as bitter apple. It is a native plant of North Africa, being common throughout Morocco, Egypt and Sudan (AlGhamdi et al., 2009). It has been used in herbal treatment of diabetes (Karim et al., 2011), edema, bacterial infection and cancer. The aqueous pulp extract of fruit is used for kidney, liver functions treatment (Rahbar and Nabipour, 2010). The phenolic compounds isolated from plants are of great interest due to their antioxidative and anticarcinogenic activity. They play a very important role in absorbing and neutralizing free radicals. They contain not only minerals and primary metabolite but also a diverse array of secondary metabolite with antioxidant potential (Chanda et al., 2011).

In the present investigation of $C$. colocynthis, we report the isolation and structural elucidation of two new alkaloids 1,2 and two flavonoids 3, 4 that has not been previously investigated with respect to its alkaloid and flavonoid constituents. 
Table 1. NMR data of compounds 1 and 2 .

\begin{tabular}{|c|c|c|c|c|c|c|}
\hline & \multicolumn{3}{|c|}{1} & \multicolumn{3}{|c|}{2} \\
\hline & ${ }^{1} \mathrm{H}$ & ${ }^{13} \mathrm{C}$ & HMBC & ${ }^{1} \mathrm{H}$ & ${ }^{13} \mathrm{C}$ & HMBC \\
\hline 1 & - & - & - & - & - & - \\
\hline 2 & - & $125.0^{\mathrm{s}}$ & & - & 119.95 & \\
\hline 3 & $6.21^{\mathrm{s}}$ & $100.3^{d}$ & C-5, C-9, C-10 & $6.62^{\mathrm{s}}$ & $99.8^{d}$ & C-1, C-4, C-5, C-10 \\
\hline 4 & - & $178.9^{s}$ & & - & $164.2^{\mathrm{s}}$ & \\
\hline 5 & $8.35^{\mathrm{brd}}$ & $125.3^{d}$ & C-4, C-7, C-10 & $8.18^{\mathrm{brd}}$ & $121.5^{d}$ & C-7, C-9 \\
\hline 6 & $7.32^{\text {brt }}$ & $123.5^{d}$ & & $7.42^{\text {brt }}$ & $124.8^{d}$ & \\
\hline 7 & $7.58^{\mathrm{dt}}$ & $131.7^{d}$ & & $7.63^{\mathrm{dt}}$ & $129.7^{d}$ & C-8, C-9 \\
\hline 8 & $7.72^{\mathrm{brd}}$ & $118.3^{d}$ & C-5, C-9, C-10 & $7.97^{\text {brd }}$ & $128.2^{d}$ & \\
\hline 9 & - & $154.7^{\mathrm{s}}$ & & - & $149.6^{s}$ & \\
\hline 10 & - & $140.5^{s}$ & & - & $162.3^{s}$ & \\
\hline OMe & - & - & & $4.05^{s}$ & $55.6^{q}$ & C-4, C-10 \\
\hline $\mathrm{NMe}$ & - & - & & - & - & \\
\hline $1^{\prime}$ & $2.63^{t}$ & $34.3^{t}$ & & $2.85^{\mathrm{t}}$ & $39.6^{t}$ & C-3, C-4 \\
\hline $2^{\prime}$ & $1.70^{\text {brs }}$ & $28.8^{t}$ & & $1.8^{\mathrm{m}}$ & $23.7^{t}$ & \\
\hline $3^{\prime}$ & $1.50^{\mathrm{brs}}$ & $28.8^{t}$ & & $1.6^{\mathrm{m}}$ & 30.1 & \\
\hline $4^{\prime}$ & $1.20^{\mathrm{brs}}$ & $28.8^{t}$ & & $1.28^{\mathrm{m}}$ & 29.0 & \\
\hline $5^{\prime}$ & $1.20^{\mathrm{brs}}$ & $28.8^{t}$ & & $1.30^{\mathrm{m}}$ & 29.3 & \\
\hline $6^{\prime}$ & $1.20^{\mathrm{brs}}$ & $28.8^{t}$ & & $1.32^{\mathrm{m}}$ & 29.9 & \\
\hline $7^{\prime}$ & $2.38^{t}$ & $43.6^{t}$ & & $2.42^{t}$ & 43.7 & \\
\hline $8^{\prime}$ & - & $210.5^{s}$ & & - & 209.5 & \\
\hline $9^{\prime}$ & $2.1^{\mathrm{s}}$ & $29.8^{q}$ & C-6 $6^{\prime}$, C-7', C-9' & $2.18^{\mathrm{s}}$ & 29.4 & C-7', C-8' \\
\hline $10^{\prime}$ & - & - & & - & - & \\
\hline
\end{tabular}

\section{MATERIALS AND METHODS}

\section{General procedures}

UV shift reagents were prepared according to standard procedures (Mabry et al., 1970; Markham, 1982). IR: Perkin - Elmer Model 983 in $\mathrm{CHCl}_{3} .{ }^{1} \mathrm{H}$ and ${ }^{13} \mathrm{CNMR}$ in Bruker $\mathrm{AC} 200 \mathrm{~L}$ instrument 200 and $50.32 \mathrm{MHz}$ and for the 2D exp. 500 and $125 \mathrm{MHz}$, respectively with TMS as int. standard. HRMS: VG Zab Spec GC - MS spectrometer.

\section{Plant materials}

The aerial parts of $C$. colocynthis were collected in June 2010 from plants growing wild in the Mediterranean Coastal Strip, Egypt. The plant identify was verified by plant taxonomist. A voucher specimen has been deposited at the Herbarium of the Botany Department, Faculty of Science, Cairo University. The collected plant samples of C. colocythis were washed with distilled water and then air dried for two weeks. The dried samples were homogenized with electrical grinder and finally stored in airtight bottles before analysis.

\section{Extraction and isolation}

Dried and powdered aerial parts $(1 \mathrm{~kg})$ were extracted with $\mathrm{MeOH}$ and the extract evaporated to dryness under reduced pressure. The residue $(2.5 \mathrm{~g})$ was acidified with $0.1 \mathrm{~N} \mathrm{H}_{2} \mathrm{SO}_{4}$ and extracted with $\mathrm{CHCl}_{3}$. The acid soluble part was basified with $\mathrm{NH}_{4} \mathrm{OH}$ (Balbaa et al., 1981) and extracted with $\mathrm{CHCl}_{3}$. The $\mathrm{CHCl}_{3}$ extract $(1.3 \mathrm{~g})$ was fractionated on a basic $\mathrm{AL}_{2} \mathrm{O}_{3}$ column $(5 \times 70 \mathrm{~cm})$ eluting with hexane (fraction $\mathrm{A}$ ), followed by a gradient of $\mathrm{CH}_{2} \mathrm{Cl}_{2}$ and ethyl acetate up to $100 \%$ (fraction B). Fraction A had yielded compound $1(75 \mathrm{mg})$ and fraction B has compound $2(35 \mathrm{mg})$. Dried aerial parts of $C$. colocynthis $(500 \mathrm{~g})$ were extracted with $\mathrm{MeOH}$ for $6 \mathrm{~h}$. The collected methanol $(\mathrm{MeOH})$ extracts were concentrated to dryness under reduced pressure. The residue $(4.5 \mathrm{~g})$ was partitioned between 1: 1 EtOAc / $\mathrm{H}_{2} \mathrm{O}$. The EtOAc layer was concentrated to give residue $(3.4 \mathrm{~g})$ and then applied to silica gel column eluted with $n$ - hexane - EtOAc $(1: 1)$. The fraction was applied to a porous polymer Diaion $\mathrm{HP}-20\left(\mathrm{H}_{2} \mathrm{O}-\mathrm{MeOH}\right.$ gradient $)$ followed by MPLC silica gel, $\left(\mathrm{CH}_{2} \mathrm{Cl}_{2}-\mathrm{MeOH}\right.$ gradient) to give compound $3(35 \mathrm{mg})$ and compound $4(25 \mathrm{mg})$.

\section{Identification of compounds}

Compound (1): 2-(Nonan-8-one)-(1H)-4-quinolone: UV $\lambda \underset{\max }{\mathrm{MeOH}} \mathrm{nm}$

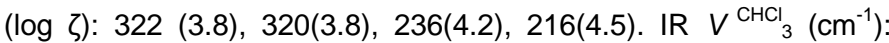
2925, 2850, 1710, 1640, 1595, 1560, 1510, 1460, 1420, 1360, $1190,1160,1120,990,840,760 .{ }^{1} \mathrm{H}$ and ${ }^{13} \mathrm{CNMR}\left(\mathrm{CDCl}_{3}\right)$ are tabulated in Table 1. MS m/z (rel.int.): $385\left[\mathrm{M}^{+}\right.$(14), $270[\mathrm{M}-\mathrm{Me}]^{+}$ (8), $242[\mathrm{M}-\mathrm{COMe}]^{+}(47), 228\left[242-\mathrm{CH}_{2}\right]^{+}(49), 214\left[228-\mathrm{CH}_{2}\right]^{+}(20)$, $200\left[214-\mathrm{CH}_{2}\right]^{+}(11), 186\left[200-\mathrm{CH}_{2}\right]^{+}(36), 172\left[186-\mathrm{CH}_{2}\right]^{+}(78), 159$ $\left[\mathrm{M}_{-} \mathrm{C}_{8} \mathrm{H}_{14} \mathrm{O}\right]^{+}(100), 130$ (37), 77 (7).HR-MS m/z:285.1832. calc. for $\mathrm{C}_{18} \mathrm{H}_{23} \mathrm{NO}_{2}$ 285. 1829.

Compound (2): 2-(Nonan-8-one) 4-methoxy-quinoline: UV $\mathrm{MeOH}$

$\lambda{ }_{\max }^{\mathrm{man}}(\log \zeta): 312(\mathrm{sh}), 314$ (2.8), 300 (2.9), 228 (4.5). IR $V$ $\mathrm{CHCl}_{3}\left(\mathrm{~cm}^{-1}\right): 2930,2850,1705,1595,1565,1510,1450,1430,1370$, 1190, 1150, 1140, 1000, 980, 840,760. ${ }^{1} \mathrm{H}$ and ${ }^{13} \mathrm{CNMR}\left(\mathrm{CDCl}_{3}\right)$ resulted as shown in Table 1. MS m/z (rel. int.) $299[\mathrm{M}]^{+}$(40), 284 
Table 2. ${ }^{13} \mathrm{CNMR}$ spectral data for compounds 3 and 4 (400 $\mathrm{MHz}, \mathrm{CDCl}_{3}$ ).

\begin{tabular}{|c|c|c|}
\hline $\begin{array}{l}\text { Compound } \\
\text { Carbon }\end{array}$ & 3 & 4 \\
\hline 2 & 77.7 & 164.5 \\
\hline 3 & 29.5 & 102.7 \\
\hline 4 & 19.3 & 182.4 \\
\hline 5 & 158.5 & 152.7 \\
\hline 6 & 91.4 & 132.6 \\
\hline 7 & 159.4 & 156.3 \\
\hline 8 & 93.4 & 94.4 \\
\hline 9 & 156.8 & 152.2 \\
\hline 10 & 103.0 & 106.0 \\
\hline $1^{\prime}$ & 135.6 & 121.2 \\
\hline $2^{\prime}, 6^{\prime}$ & $106.7,119.6$ & 126.6 \\
\hline $3 /, 5 /$ & $108.1,147.2$ & 115.9 \\
\hline $4^{\prime}$ & 147.8 & 161.5 \\
\hline OMe & 55.4 & 60.6 \\
\hline \multicolumn{3}{|l|}{ Glucosyl } \\
\hline $1^{\prime \prime}$ & & 100.1 \\
\hline $2^{\prime \prime}$ & & 73.2 \\
\hline $3^{\prime \prime}$ & & 76.6 \\
\hline $4^{\prime \prime}$ & & 70.4 \\
\hline $5^{\prime \prime}$ & & 74.1 \\
\hline $6^{\prime \prime}$ & & 63.7 \\
\hline \multicolumn{3}{|l|}{ Coumaroyl } \\
\hline $1^{\prime \prime \prime}$ & & 125.0 \\
\hline $2^{\prime \prime \prime}, 6^{\prime \prime \prime}$ & & 130.0 \\
\hline $3^{\prime \prime \prime}, 5^{\prime \prime \prime}$ & & 116.2 \\
\hline $4^{\prime \prime \prime}$ & & 159.8 \\
\hline $7^{\prime \prime \prime}$ & & 113.7 \\
\hline $8^{\prime \prime \prime}$ & & 145.2 \\
\hline $9^{\prime \prime \prime}$ & & 166.7 \\
\hline
\end{tabular}

$[\mathrm{M}-\mathrm{Me}]^{+}(14), 256$ [284-CO $^{+}(58), 242$ [256- $\left.^{-} \mathrm{CH}_{2}\right]^{+}(66), 228$ [242$\left.\mathrm{CH}_{2}\right]^{+}(2 \mathrm{~S}), 214\left[228-\mathrm{CH}_{2}\right]^{+}, 200\left[214-\mathrm{CH}_{2}\right]^{+}(74), 186\left[200-\mathrm{CH}_{2}\right]^{+}$

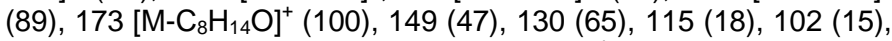
83 (8), 71 (17). HR-MS m/z: 299. $1978[\mathrm{M}]^{+}$, calc. for $\mathrm{C}_{19} \mathrm{H}_{25} \mathrm{NO}_{2}$ 299.1985.

Compound (3): (2S)- 3', 4 - Methylenedioxy-5, 7-dimethoxy flavan: UV $\lambda{ }_{\max }^{\mathrm{MeOH}} \mathrm{nm}(\log \zeta): 283$ (3.83), 230 (5.22). IR $V^{\mathrm{CHCl}}$ $\left(\mathrm{cm}^{-1}\right): 3060,2940,2840,1620,1595,1495,1440,1250,1200$, 1140, 1100. ${ }^{1} \mathrm{HNMR}\left(400 \mathrm{MHz}, \mathrm{CDCl}_{3}\right){ }^{13} \mathrm{CNMR}\left(400 \mathrm{MHz}, \mathrm{CDCl}_{3}\right)$ Table 2. HR-MS m/z: 314 . $1145\left(\mathrm{M}^{+}\right.$. calc. for $\mathrm{C}_{18} \mathrm{H}_{18} \mathrm{O}_{5}$; 314. 1154). MS m/z (rel. int.): $314\left[\mathrm{M}^{+},(100), 283\right.$ (8), 166(9), 148 (59), 147 (26), $138(14)$.

Compound (4): $\begin{gathered}\text { Hispidulin 7-(6-E-P-coumaroyl- } \beta-D- \\ \mathrm{MeOH}\end{gathered}$ glucopyranoside): UV $\lambda{ }_{\max }^{\mathrm{MeOH}} \mathrm{nm}(\log \zeta): 338(4.46), 275(4.26)$,

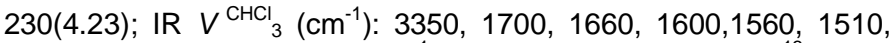
1495, 1300, 1260, 1189, 1080. ${ }^{1} \mathrm{HNMR}\left(400 \mathrm{MHz}, \mathrm{CDCl}_{3}\right),{ }^{13} \mathrm{CNMR}$ (400 MHz, $\mathrm{CDCl}_{3}$ ) Table 2. HR-MS m/z: 608. $1573\left(\mathrm{M}^{+}\right.$. calc. for $\mathrm{C}_{31} \mathrm{H}_{28} \mathrm{O}_{13}$; 608. 1529). MS m/z (rel. int.): 300(100), 285 (68), 257 (63), 167(12), 164(13), 147(24), 139(15), 119(22), 69(50).

\section{RESULTS AND DISCUSSION}

Two new alkaloids (compounds 1 and 2) were isolated from the aerial parts of $C$. colocynthis. The UV spectra for compound 1 showed typical 4-quinolone peaks at 332, 320,236 and $216 \mathrm{~nm}$. The IR spectrum showed aromatic signals at 1595 and $1510 \mathrm{~cm}^{-1}$. The ${ }^{1}$ HNMR spectra of compound 1 showed quinolone structure with the broad doublet. Also the ${ }^{1}$ HNMR spectrum showed the signals for the aliphatic side chain as given in Table 1. The placement of the side chain was decided by HMBC experiment for compounds 1 and $2 .{ }^{13} \mathrm{CNMR}$ (Table 1 ). From the HMBC experiments the structure of compound 1 was assigned as 2-(nonan-8-one)- $(1 \mathrm{H})-4$ quinolone. HR-MS indicated the molecular formula $\mathrm{C}_{18} \mathrm{H}_{23} \mathrm{NO}_{2}(\mathrm{~m} / \mathrm{z}$ 285 , 1832). Thus, compound 1 was assigned as 2(nonan-8-one)-(1H)-4-quinolone which was not previously isolated from the aerial parts of $C$. colocynthis (Figure 1 ). Compound 2: The molecular formula of the second new compound 2 as $\mathrm{C}_{19} \mathrm{H}_{25} \mathrm{NO}_{2}$ calculated from its HR-MS ( $\mathrm{m} / \mathrm{z} 299,1978)$; indicated eight degrees of unsaturation, two of which were accounted for the bicyclic ring system, one for the carbonyl group on the side chain and the remaining five for the double bonds. The ${ }^{1} \mathrm{HNMR}$ spectrum showed the chemical shift of the aromatic proton $\mathrm{H}-5$ in a fairly lower field at $\delta 8.18(1 \mathrm{H}$, brd, $\mathrm{J}=8$ $\mathrm{Hz}, \mathrm{H}-5$ ). The chemical shift of the methoxy group at $\delta$ 4.05 an O-methyl rather than an $\mathrm{N}$-methyl group correlated with the aromatic character of the ring system (Table 1). The IR spectrum showed the side chain carbonyl group at $1705 \mathrm{~cm}^{-1}$ and aromatic signals at $1595,1565,1510 \mathrm{~cm}^{-1}$. The UV spectrum showed the presence of conjugated aromatic system with the maxima at 312 (sh), 300 and $228 \mathrm{~nm}$. The correlation of the protons and carbons were followed from the HMBC spectrum and unambiguous assignment of the molecule (Table 1). The spectral data showed the structure of compound 2 as 2-(nonan-8-one)-4-methoxy-quinoline (Figure 1).

Furthermore, two flavonoids were isolated from aerial parts of the plant. These were identified as (2S)-3, 4 . methylenedioxy-5, 7-dimethoxy flavan (Figure 2, compound 3) and hispidulin 7-(6-E-P-coumaroyl- $\beta$-Dglucopyranoside) (Figure 2, compound 4). The molecular formula of compound 3 was determined as $\mathrm{C}_{18} \mathrm{H}_{18} \mathrm{O}_{5}$ on the basis of HR-MS. The broad band decoupled ${ }^{13} \mathrm{CNMR}$ spectrum showed 18 carbon signals. The IR spectrum showed absorption bands at 1595 and $1495 \mathrm{~cm}^{-1}$ which were assignable to an aromatic ring. The aforementioned data and UV spectrum ( $\lambda$ max) at 230 and $283 \mathrm{~nm}(\mathrm{sh})$ suggested aflavan nature for compound 3 , which was further evidenced by the analysis of the ${ }^{1} \mathrm{HNMR}$ and ${ }^{1} \mathrm{H}$ ${ }^{1} \mathrm{H}$ COSY spectra. The ${ }^{1} \mathrm{HNMR}$ spectrum showed proton signals at $\delta 6.07$ and 6.11 . Also, the proton signals were at $\delta 6.76,6.87$ and 6.92. The $\mathrm{H}-2, \mathrm{H}_{2}-3$ and $\mathrm{H}_{2}-4$ signals were at $(\delta 4.87),(\delta 1.96,2.13)$ and $(\delta 2.61,2.73)$, respectively. Additionally, the ${ }^{1} \mathrm{HNMR}$ spectrum showed two methoxy signlets at $\delta 3.74,3.78$ and one 


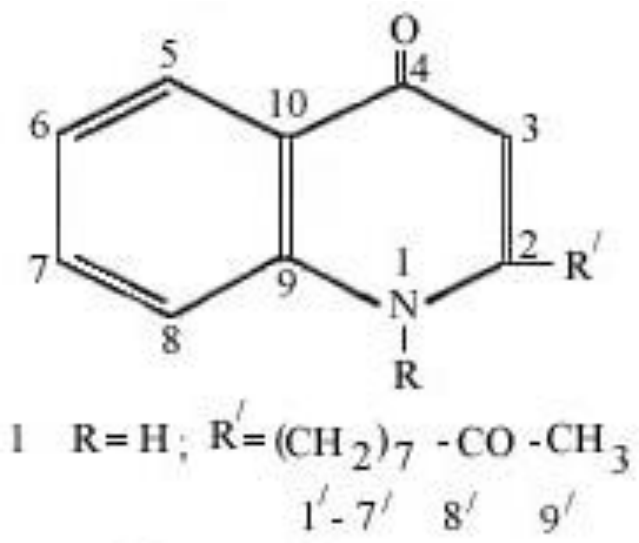

\section{Compound 1}

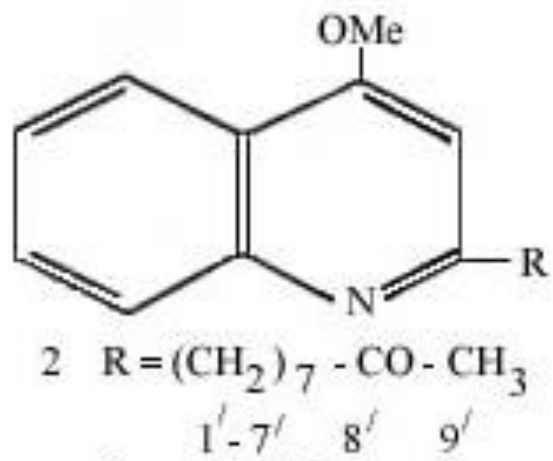

Compound 2

Figure 1. Alkaloids (compounds 1 and 2).

methylenedioxy signal at $\delta 5.94$. The ${ }^{13} \mathrm{CNMR}$ spectra revealed $\mathrm{C}_{6}-\mathrm{C}_{3}$ signals at $\delta 19.3$ (C-4), 29.5 (C-3), 77.7 (C-2), 91.4 (C-6), 93.4 (C-8), 103.0 (C-10), 156.2 (C-9), 158.5, $159.4(\mathrm{C}-5,7)$ and $\mathrm{C}_{6}$ signals at $\delta 106.7(\mathrm{C}-2)$, $108.1\left(\mathrm{C}-5^{\prime}\right), 119.6\left(\mathrm{C}-6^{\prime}\right), 135.6\left(\mathrm{C}-1^{\prime}\right), 147.2,147.8$ (C$\left.3^{\prime}, 4^{\prime}\right)$. In addition, two methoxyl signals were found at $\delta$ 55.3 (C-OMe) and 55.4 (C-OMe) and one methylenedioxy signal was at $\delta 101.0$ (Table 2, Figure 2). Atypical fragmentation at $\mathrm{m} / \mathrm{z} 148$ from MS spectrum suggested one methlendioxy unit in ring $\mathrm{B}$. The $\mathrm{H}-2$ proton formed a doublet of doublets with trans coupling ${ }^{3} \mathrm{~J}(10.5 \mathrm{~Hz})$ and cis coupling ${ }^{3} \mathrm{~J}(1.8 \mathrm{~Hz})$ suggesting that this methine proton must be axial. The absolute configuration at position 2 was determined as $2 S$ by comparing the negative cotton effect at $281 \mathrm{~nm}$ in CD experiment with the authentic (2S)-4-hydroxy-5, 7, 3-trimethoxyflavan. From the aforementioned evidence, compound 3 was determined to be (2S)-3,4-methylenedioxy -5, 7dimethoxyflavan.

The molecular formula of compound 4 was determined as $\mathrm{C}_{31} \mathrm{H}_{28} \mathrm{O}_{13}$ on the basis of HR-MS. The IR spectrum revealed hydroxyl $\left(3350 \mathrm{~cm}^{-1}\right)$, conjugated ester (1700 $\left.\mathrm{cm}^{-1}\right), \quad \alpha, \quad \beta$-unsaturated carbonyl $\left(1660 \mathrm{~cm}^{-1}\right)$, and aromatic absorptions $\left(1600,1560\right.$ and $\left.1500 \mathrm{~cm}^{-1}\right)$. The
UV spectrum in methanol exhibited absorptions ( $\lambda$ max) at 338 and $275 \mathrm{~nm}(\mathrm{sh})$ and 230 (sh). The ${ }^{1} \mathrm{HNMR},{ }^{1} \mathrm{H}-{ }^{1} \mathrm{H}$ COSY, ${ }^{13}$ CNMR and HMBC spectra displayed characteristic signals for the flavone, glucose and P-coumaroyl moieties.

The ${ }^{1} \mathrm{HNMR}$ and ${ }^{1} \mathrm{H}-{ }^{1} \mathrm{H}$ COSY spectra showed a methoxyl group $\delta 3.66(6-\mathrm{OMe})$, two singlet protons at $\delta$ $6.90(1 \mathrm{H}, \mathrm{s}, \mathrm{H}-3), 7.08(1 \mathrm{H}, \mathrm{s}, \mathrm{H}-8)$, three para substituted aromatic protons at $\delta 7.00(2 \mathrm{H}, \mathrm{d}, \mathrm{J}=8.4, \mathrm{H}-3,5)$, $8.02\left(2 \mathrm{H}, \mathrm{d}, \mathrm{J}=8.4, \mathrm{H}-2^{\dagger}, 6^{\dagger}\right)$ and a hydrogen bonded hydroxyl group at $\delta 13.06(1 \mathrm{H}, \mathrm{br}, \mathrm{s}, 5-\mathrm{OH})$. From the aforementioned data, the flavone moiety was suggested as hispidulin. Moreover, glucose moiety signals were found at $\delta 5.30\left(1 \mathrm{H}, \mathrm{d}, \mathrm{J}=8.4, \mathrm{H}-1^{\prime \prime}\right), 3.39\left(1 \mathrm{H}, \mathrm{m}, \mathrm{H}-4^{\prime \prime}\right)$, $3.50\left(2 \mathrm{H}, \mathrm{m}, \mathrm{H}-2^{\|}, 3^{\|}\right), 3.96\left(1 \mathrm{H}, \mathrm{br}, \mathrm{t}, \mathrm{J}=8.4, \mathrm{H}-5^{\|}\right), 4.30$ $\left(1 \mathrm{H}, \mathrm{dd}, \mathrm{J}=11.2,7.6, \mathrm{H}-6^{\prime \prime}\right.$ a) and $4.57(1 \mathrm{H}, \mathrm{br}, \mathrm{d}, \mathrm{J}=$ $11.2, H-6^{\|}$b). The anomeric hydrogen signal at $\delta 5.30$ $\left(1 \mathrm{H}, \mathrm{d}, \mathrm{J}=8.4 \mathrm{~Hz}, \mathrm{H}-1^{\prime \prime}\right)$ supported the $\beta$-pyranoside configuration. Compound 4 (Table 2) revealed extra ${ }^{1} \mathrm{HNMR}$ signals at $\delta 7.33\left(2 \mathrm{H}, \mathrm{d}, \mathrm{J}=8.4, \mathrm{H}-2^{\prime \prime \prime}, 6^{\prime \prime \prime}\right), 6.66$ $\left(2 \mathrm{H}, \mathrm{d}, \mathrm{J}=8.4, \mathrm{H}-3^{\prime \prime \prime}, 5^{\prime \prime \prime}\right), 6.36\left(1 \mathrm{H}, \mathrm{d}, \mathrm{J}=15.6, \mathrm{H}-8^{\prime \prime \prime}\right)$, $7.54\left(1 \mathrm{H}, \mathrm{d}, \mathrm{J}=15.6, \mathrm{H}-7^{1 \mathrm{il}}\right)$ and extra ${ }^{13} \mathrm{CNMR}$ signals at $\delta$ 125.0, 130.0, 116.2, 159.8, 113.7, 145.2 and 166.7. These extra NMR signals gave the evidences of the 


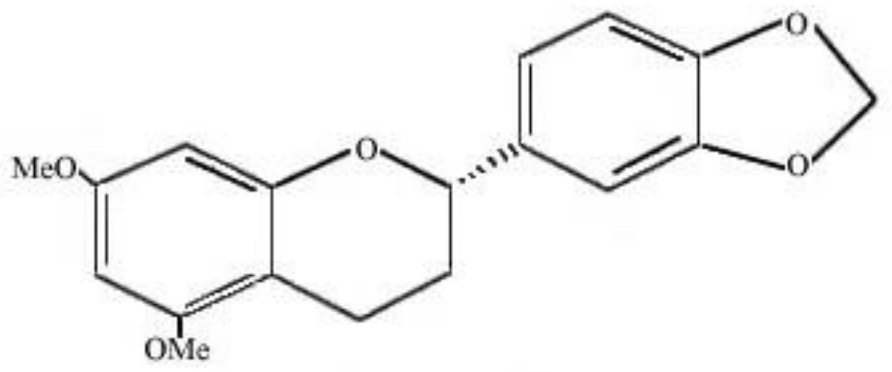

Compound 3

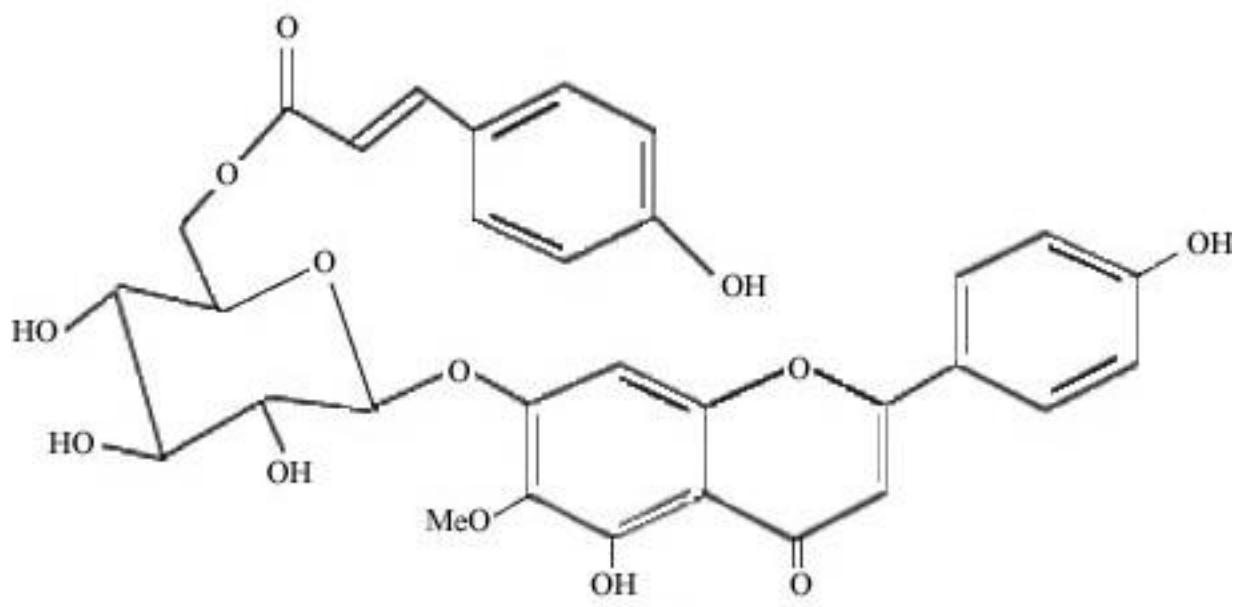

Compound 4

Figure 2. Flavonoids (compounds 3 and 4).

existence of an E-P-coumaroyl group in compound 4 . The downed field shifted $\mathrm{H}-\mathrm{G}^{\|}$resonance suggested that the E-P-coumaroyl moiety was adjacent to C-6". Finally, through $\mathrm{HMBC}$ results, the attachment positions were determined. The methoxyl signal at $\delta 3.66(\mathrm{~s}, 6-\mathrm{OMe})$ showed at ${ }^{3} \mathrm{~J}$ correlation to a carbon at $\delta 132.6$ (C-6) suggesting the methoxl group was connected to C-6 position in hispidulin moiety. The anomeric proton of the glucose unit $\left(\delta 5.30, \mathrm{H}-1^{11}\right)$ showed a ${ }^{3} \mathrm{~J}$ correlation to a carbon of hispidulin ( $\delta$ 157.6, C-7) indicating the attachment of the glucoside group at position C-7. Further, a ${ }^{3} \mathrm{~J}$ interaction between $\mathrm{H}-6$ " 4.30, $\mathrm{H}-6^{\prime \prime}$ ) and the P-coumaroyl carbonyl carbon ( $\delta$ 166.7, C-9 ${ }^{\text {III) }}$ suggested the attachment of the Pcoumaroyl ester at C-6" of the glucose moiety (Figure 2). From the aforementioned evidences, the structure of compound 4 was determined to be hispidulin 7- (6-E-Pcoumaroyl- $\beta$-D-glucopyranoside).

\section{ACKNOWLEDGEMENT}

This research was supported by a grant from the Research Center of the Center for Female Scientific and Medical Colleges, King Saud University.

\section{REFERENCES}

Abbas D, Simon G, Ali R, Hossein N, Masoud M, Lutfun N, Satyaitt D (2006). Flavone C-glycoside and cucurbitacin glycoside from Citrullus colocynthis. DARA 14(3):109-114.

Adam S, Al-Yahya M, Al-Farhan A (2001). Response of Najdi sheep to oral administration of Citrullus colocynthis fruits. Small Rumin. Res. 40:239-244.

Al-Ghamdi FA, Al-Zahrani HS, Al-Amer KH (2009). Phytosociological studies of Citrullus colocynthis L., growing in different altitudinal sites in Saudi Arabia. Pak. J. Biol. Sci. 10:779-785.

Balbaa S, Hilal SH, Zaki AY (1981). Medical plant constituents. $3^{\text {rd }}$ Ed., General Organization for University and School Books, Cairo. pp 300-315.

Chanda S, Dave R, Kaneria M (2011). In vitro antioxidant property of some Indian medicinal plants. Res. J. Med. Plant 5:169-179.

Chaudhary SA, Al-jowaid AA (1999). Vegetation of the Kingdom of Saudi Arabia. National Agriculture and Water Research Center. Ministry of Agriculture and Water. Riyadh, Saudi Arabia. p. 689.

Gordon MC, David JN (2001). Natural product drug discovery in the next millennium. Pharm. Biol. 39:8-17.

Hatam NA, Whiting DA, Yousif NJ (1989). Cucurbitacin glycosides from Citrullus colocynthis. Phytochem. 28:1268-1271.

Jayaprakasam B, Seeram N, Nair M (2003). Anticancer and antiinflammatory activites of cucurbitacins from Cucurbita andreana. Cancer Lett. 189:11-16.

Karim A, Nouman M, Munir S, Sattar S (2011). Pharmacology and phytochemistry of Pakistani herbs and herbal drugs used for treatment of diabetes. Int. J. Pharmacol. 7:419-439.

Karthikeyan A, Shanthi V, Nagasathaya A (2009). Preliminary phytochemical and antibacterial screening of crude extract of the leaf 
of Adhatoda vasica, L. Int. J. Green Pharm. 3:78-80.

Maatooq GT, El-Sharkawy SH, Afifi MS, Rosazza PN (1997). C-PHydroxybenzoyl-glycoflavanones from Citrullus colocynthis. Phytochem. 44:187-190.

Mabry TJ, Markham KR, Thomas MP (1970). The systematic identification of flavonoids. Springer, berlin, Germany. pp 18-32.

Markham KR (1982). Techniques of flavonoid identification. Academic Press, London, UK. pp 43-56.

Rahbar AR, Nabipour I (2010). The hypolipidemic effect of Citrullus colocynthis on patients with hyperlipidemia. Pak. J. Biol. Sci. 13:1202-1207.

Seger C, Sturm S, Mair ME, Ellmerer EP, Stuppner H (2005). ${ }^{1} \mathrm{H}$ and ${ }^{13}$ CNMR signal assignment of cucurbitacin derivatives from Citrullus colcoynthis (L.) Schrader and Ecballium elaterium (L.) (Cucurbitaceae). Magn. Reson. Chem. 43(6):489-491.

Sturm S, Schveider P, Seger C, Stuppner H (2009). Analysis of Citrullus colocynthis cucurbitacin derivatives with HPLC - SPE NMR. Scientia Pharm. 77:254-257.
Sunil K, Dinesh K, Manjusha M, Kamal S, Hidhan S, Bhoodev V (2008). Antioxidant and free radical scavenging potential of Citrullus colocynthis (L.) Schrad. Methanolic fruit extract. Acta Pharm. 58:215220.

Täckholm V (1974). Students' Flora of Egypt. $2^{\text {nd }}$ Ed., Cairo University, Cooperative printing Company, Beirut, Lebanon. pp $374-376$. 